J. Dairy Sci. 95:3559-3568

http://dx.doi.org/10.3168/jds.2011-5125

(C) American Dairy Science Association ${ }^{\circledR}, 2012$.

\title{
Enzymatic characterization of transglutaminase from Streptomyces mobaraensis DSM 40587 in high salt and effect of enzymatic cross- linking of yak milk proteins on functional properties of stirred yogurt
}

\author{
L. Zhang, ${ }^{*}$ L. Zhang, ${ }^{* 1}$ H. Yi, ${ }^{*}$ M. Du, ${ }^{*}$ C. Ma, $†$ X. Han, ${ }^{*}$ Z. Feng,† Y. Jiao, ${ }^{\star}$ and Y. Zhang‡ \\ *School of Food Science and Engineering, Harbin Institute of Technology, Harbin 150090, China \\ †College of Food Science, Northeast Agricultural University, Harbin 150090, China \\ ¥National Key Laboratory of Veterinary Biotechnology, Harbin Veterinary Research Institute, Chinese Academy of Agricultural Sciences, \\ Harbin 150001, China
}

ABSTRACT

Streptomyces transglutaminase (TGase) purified from high-salt medium was characterized and applied into yak yogurts. The purified enzyme presented a Michaelis constant of $40.47 \mathrm{mmol}$ and a maximum velocity of $44.44 \mathrm{U} / \mathrm{mg}$ of protein for N-carboxybenzoyl-Lglutaminyl-glycine in the hydroxamate procedure. The purified TGase exhibited optimum activity at $55^{\circ} \mathrm{C}$ and $\mathrm{pH}$ 6.0. The enzyme was not stable above $50^{\circ} \mathrm{C}$ and was stable within a $\mathrm{pH}$ range of 5.0 to 10.0 at $4^{\circ} \mathrm{C}$ for $12 \mathrm{~h}$ and $\mathrm{pH} 5.0$ to 9.0 at $37^{\circ} \mathrm{C}$ for $30 \mathrm{~min}$. The TGase activity was not affected by $\mathrm{Ca}^{2+}, \mathrm{K}^{+}, \mathrm{Ba}^{2+}$, or $\mathrm{Na}^{+}$, but slightly inhibited by $\mathrm{Fe}^{2+}, \mathrm{Mg}^{2+}$, and $\mathrm{Mn}^{2+}$, and strongly by $\mathrm{Cu}^{2+}$ and $\mathrm{Zn}^{2+}$. To explore yak milk products, it was used to produce yogurt and TGase was used. It was found that TGase-catalyzed cross-linking was effective in improving functional properties of stirred yak yogurt. Treated yogurt produced a strong acid gel, higher consistency, cohesiveness, index of viscosity, and creamier mouth feel than the untreated product. Furthermore, yak yogurt treated with TGase presented lower wet yak hair or sweat odor, or both. Therefore, TGase can be used to pave the way for exploration of novel yak products to overcome the issues of peculiar wet yak hair or sweat odor, or both.

Key words: transglutaminase, characterization, yak milk, yogurt

\section{INTRODUCTION}

Yak (Poephagus grunniens or Bos grunniens) live in extremely harsh conditions believed to be unpolluted and provide a livelihood for local people (Zhang et al., 2009). Yak milk is creamy white in color and a highly nutritious product rich in fat, protein, essential min-

Received November 7, 2011

Accepted March 10, 2012.

${ }^{1}$ Corresponding author: lanweizhang@yahoo.com.cn erals, and healthy PUFA such as conjugated linoleic acid and n-3 FA (Zeng et al., 2007; Zhang et al., 2009; Kandeepan and Sangma, 2011; Liu et al., 2011). Therefore, a growing industry interest exists in developing techniques to explore yak milk products. However, yak milk has a peculiar wet yak hair or sweat odor, or both, which is more prevalent in the winter season. People who have not tasted yak milk have to become accustomed to these characteristics. Preparation of a fermented milk product from yak milk is an excellent way to overcome this problem. Yak milk fermented products such paneer, Qula, and homemade yak yogurt can be consumed like any other fermentation products prepared from cow or buffalo milk and do not require any special adaptation.

To explore yak milk products, a commercial strain was used to produce yogurt in our laboratory. However, yak milk yogurt presented a coarse and grainy mouth feel sensation because of high fat, protein, and TS content. In the cow milk system, transglutaminase (TGase) was introduced to improve the physical, chemical, texture, and sensory characteristics of the yogurt (Yüksel and Erdem, 2010; Şanll et al., 2011), and products from enzyme-treated milk were described as being more creamy (Lorenzen et al., 2002). In addition, enzymatic crosslinking of milk proteins by transglutaminase appears to be an effective means for improving the functional properties of goat milk yogurt (Farnsworth et al., 2006). But to date, no information is available on the development and quality evaluation of TGase-treated yogurt from yak milk.

Transglutaminase [protein-glutamine: amine $\gamma$-glutamyltransferase; EC 2.3.2.13, based on recommendations of the Nomenclature Committee of the International Union of Biochemistry and Molecular Biology (IUBMB)] is the enzyme that catalyzes an acyl transfer reaction between $\gamma$-carboxyl groups of glutamine residues and $\varepsilon$-amino groups of lysine of protein substrates (Soares et al., 2004). Transglutaminase can introduce covalent crosslinking between proteins, pep- 
tides, and various amines. It is widely distributed in mammals, fish, plants, and bacteria and involved in biological processes. The production of microbial TGase proved pivotal in paving the way for food industrial applications (Motoki and Seguro, 1998). This enzyme has been used as an alternative to modification of functional properties of protein such as solubility, hydration ability, rheological and emulsifying properties, and heat stability in model systems (DeJong and Koppelman, 2002; Lee and Chin, 2010; Tang et al., 2011).

Recently, we improved the production of TGase by supplementing excessive $\mathrm{MgCl}_{2}$ into medium. To modify yak yogurt, TGase purified from this kind of culture was characterized and added to yak milk yogurt and the physicochemical and sensory quality attributes were compared. This was intended to elucidate the effect of enzyme on the quality of yak milk yogurt.

\section{MATERIALS AND METHODS}

\section{Microorganisms and Culture}

Streptomyces mobaraensis DSM 40587 [Deutsche Sammlung von Mikroorganismen und Zellkulturen (DSMZ) GmbH, Braunschweig, Germany] was used throughout this study. The strain was cultivated on malt-meat agar $(\mathrm{pH} 7.0)$ at $30^{\circ} \mathrm{C}$ for 1 wk. The seed culture medium was composed of $2 \%$ Polypeptone,

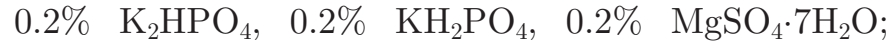
$\mathrm{pH}$ adjusted to 7.0 before autoclaving. The fermentation medium consisted of $(\mathrm{pH} 7.0) 3 \%$ polypeptone, $1 \%$ soluble starch, $1 \%$ fructose, $0.2 \% \mathrm{~K}_{2} \mathrm{HPO}_{4}, 0.1 \%$ $\mathrm{MgSO}_{4} \cdot 7 \mathrm{H}_{2} \mathrm{O}$, and $2 \% \mathrm{MgCl}_{2} \cdot 7 \mathrm{H}_{2} \mathrm{O}$. For seed preparation, the microorganism from a fresh slant tube was inoculated into $50 \mathrm{~mL}$ of fresh seed medium in $250-\mathrm{mL}$ flasks and cultivated on a rotary shaker at $200 \mathrm{rpm}$ and $30^{\circ} \mathrm{C}$ for $48 \mathrm{~h}$. Seed culture $(10 \%, \mathrm{vol} / \mathrm{vol})$ was then inoculated into $50 \mathrm{~mL}$ of fresh fermentation medium in 250-mL flasks and cultivated on a rotary shaker at 200 rpm and $30^{\circ} \mathrm{C}$ for $96 \mathrm{~h}$.

\section{Purification of TGase}

The 96-h culture medium of $S$. mobaraensis was passed through filter paper and a $0.22-\mu \mathrm{m}$ filter membrane to remove mycelia. The filtered liquid was directly concentrated by ultrafiltration with a Millipore Labscale TFF System (Millipore Corp., Bedford, MA) with a $30 \mathrm{kDa}$ cut-off. Six milliliters of ultrafiltered culture broth was loaded on a Sephadex G-75 chromatography column $(1.6 \times 60 \mathrm{~cm}$; GE Healthcare, Uppsala, Sweden $)$ previously equilibrated with $50 \mathrm{mmol} / \mathrm{L}$ of phosphate buffer (pH 6.0) and eluted with the same buffer at a flow rate of $0.25 \mathrm{~mL} / \mathrm{min}$. Fractions of $5 \mathrm{~mL}$ were collected and assayed for TGase activity. The enzyme solution from Sephadex G-75 was applied to a SP Sepharose High Performance column $(1.6 \times 10 \mathrm{~cm}$; GE Healthcare $)$ pre-equilibrated with $50 \mathrm{mmol} / \mathrm{L}$ of phosphate buffer ( $\mathrm{pH}$ 6.0). The column was washed extensively with the same buffer and eluted with a linear gradient of 0.0 to $0.25 \mathrm{~mol} / \mathrm{L}$ of NaCl in the same buffer at a flow rate of $3.0 \mathrm{~mL} / \mathrm{min}$. Fractions with TGase activity were pools. The purification system was an ÄKTApurifier 100 system and was equipped with a P-900 series pump, UV-900 monitor, pH/C-900 monitor, M-925 mixer, a complete set of motor valves, Frac-950 fraction collector, A-900 autosampler, and an AD-900 analog/digital converter connecting a Shimadzu 10A refractive index detector (GE Healthcare Bio-Sciences Corp., Piscataway, NJ). All steps were performed at $4^{\circ} \mathrm{C}$, unless otherwise stated.

\section{Determination of TGase Activity and Protein Concentration}

Transglutaminase activity was determined by hydroxamate formation described by Folk and Cole (1966), in which N-carboxybenzoyl-L-glutaminyl-glycine (NCBZ-Gln-Gly) was used as the substrate. One unit of TGase was defined as the amount that caused the formation of $1.0 \mu \mathrm{mol}$ of hydroxamic acid per minute at $37^{\circ} \mathrm{C}$. Protein concentration was determined by the method of Bradford (1976), using BSA (Sigma, Shanghai, China) as the standard.

\section{SDS-PAGE}

The culture, purified enzyme, and protein oligomerizations of yogurt were analyzed by SDS-PAGE according to the method of Laemmli (1970). A $12.5 \%$ separating gel was used. The electrophoreses were performed in a Mini-Protean II (Bio-Rad Laboratories Inc., Hercules, CA) at $80 \mathrm{~V}$ for $30 \mathrm{~min}$ and $120 \mathrm{~V}$ for 60 min. Electrophoresis gels were stained with Coomassie Brilliant Blue R-250. Images were scanned by the Gel Doc XR system and analyzed with the analysis software Quantity one (version 5.0.; Bio-Rad Laboratories Inc.).

\section{Determination of Kinetic Parameters}

Kinetic parameters were determined in the reaction mixtures indicated above containing variable amounts of the specific substrate N-CBZ-Gln-Gly $(0-30$ $\mathrm{mmol} / \mathrm{L})$. The values of the Michaelis constant $\left(\mathbf{K}_{\mathrm{m}}\right)$ and maximum velocity $\left(\mathrm{V}_{\max }\right)$ were determined from Lineweaver-Burk plots. 


\section{Characterization of TGase}

The $\mathrm{pH}$ optimum was determined at a fixed assay temperature of $37^{\circ} \mathrm{C}$ at various $\mathrm{pH}$ ranging from 2.0 to 10.0 using citrate-Tris-borate buffer $(50 \mathrm{mmol} / \mathrm{L})$. The $\mathrm{pH}$ stability of the purified TGase was conducted in citrate-phosphate-borate buffer $(\mathrm{pH}$ range between 2.0 and 10.0 ) at $4^{\circ} \mathrm{C}$ for $12 \mathrm{~h}$ and $37^{\circ} \mathrm{C}$ for $30 \mathrm{~min}$.

Optimum temperature for the activity of TGase was determined by carrying out the TGase assay with $\mathrm{N}$ CBZ-Gln-Gly at selected constant temperatures ranging from 20 to $70^{\circ} \mathrm{C}$. In each case, the substrate was preincubated at the required temperature. The effect of temperature on TGase stability was determined by incubating the TGase solution at various temperatures ranging from 4 to $60^{\circ} \mathrm{C}$ and then the residual TGase activity was assayed using the N-CBZ-Gln-Gly method. The TGase solutions were incubated on Tris- $\mathrm{HCl}$ buffer (20 mmol/L, pH 6.0).

The stability of TGase against several metal compounds including $\mathrm{NaCl}, \mathrm{KCl}, \mathrm{BaCl}_{2}, \mathrm{CaCl}_{2}, \mathrm{MnCl}_{2}$, $\mathrm{MgCl}_{2}, \mathrm{FeSO}_{4}, \mathrm{ZnCl}_{2}$, and $\mathrm{CuSO}_{4}$ was assessed. Transglutaminase was incubated with the salts of the abovementioned ions at concentrations of $5 \mathrm{mmol} / \mathrm{L}$ at $37^{\circ} \mathrm{C}$ for $30 \mathrm{~min}$. Sample residual activities were determined using the N-CBZ-Gln-Gly assays.

\section{Milk Chemical Analysis}

The TS (gravimetric drying at $98-100^{\circ} \mathrm{C}$ ), fat (RoseGottlieb method), ash (muffle furnace at $550^{\circ} \mathrm{C}$ ), and total nitrogen (Kjeldahl) of yak and cow milk were determined according to the methods of the Association of Official Analytical Chemists (AOAC, 2002), respectively. The total protein content was calculated from total nitrogen using a 6.38 conversion factor. The $\mathrm{pH}$ values of milk and yogurt mix samples were measured using a digital $\mathrm{pH}$ meter (basic $\mathrm{pH}$ meter PB-10; Sartorius AG, Göttingen, Germany).

\section{Preparation of Yogurt Samples}

The yak and cow milk samples were pasteurized at $95^{\circ} \mathrm{C}$ for $5 \mathrm{~min}$. Then samples were cooled rapidly to $42^{\circ} \mathrm{C}$. Transglutaminase was added at different enzyme concentrations $(0,0.25,0.5$, and $1 \mathrm{U} / \mathrm{g}$ of protein for yak milk; $0,0.5,1$, and $2 \mathrm{U} / \mathrm{g}$ of protein for yak milk). The samples were inoculated with $0.04 \%$ probiotic yogurt starter culture [YO-MIX, Yogurt Cultures, Yo-Mix 161 LYO 375 DCU; Danisco (China) Co. Ltd., Beijing, China]. For making stirred yogurt, inoculated milk was incubated at $42^{\circ} \mathrm{C}$ until the yogurt $\mathrm{pH}$ reached 4.6, cooled in an ice-water bath with overhead stirring (50 $\mathrm{rpm}$ ) for $3 \mathrm{~min}$, and then placed in refrigeration. Upon refrigeration at $4^{\circ} \mathrm{C}$ for $3 \mathrm{~d}$, the yogurt samples were examined for physical properties including viscosity and syneresis, and the yogurt samples were subjected to texture, sensory evaluation, and determination of protein oligomerization.

\section{Syneresis}

The syneresis index of different yogurt samples was determined according to the methodology proposed by Farnsworth et al. (2006), with modifications. Yogurt samples $(15 \mathrm{~g})$ were centrifuged at $350 \times g$ (model 3-30K; Sigma Laborzentrifugen GmbH, Osterode am Harz, Germany) for 10 min under refrigeration, in duplicate. The syneresis percentage was calculated by the milk whey mass separated from the gel network during centrifugation, divided by the initial yogurt mass, multiplied by 100 (Keogh and O'Kennedy, 1998) as follows:

$$
\text { Syneresis }(\%)=\frac{\text { weight of supernatant }(\mathrm{g})}{\text { weight of yogurt sample }(\mathrm{g})} \times 100 \% \text {. }
$$

\section{Texture Analysis}

For texture analysis, the yogurt samples were kept in plastic cylindrical containers (45-mm diameter) of 80 $\mathrm{mL}\left(4^{\circ} \mathrm{C}\right)$. Yogurt texture measurements were carried out with a Stable Micro Systems texturometer model TA-XT2i (Texture Technologies Corp., White Plains, NY) with a 5-kg load cell. The operating conditions were as follows: a 35-mm diameter solid rod (A/BE35) was thrust into the containers holding the test sample, so that the fluid flowed upwards through the concentric annular space. The probe was inserted into each product to a depth of $20 \mathrm{~mm}$ at a speed of $1 \mathrm{~mm} / \mathrm{s}$. Data were collected on computer and the following texture profile parameters were calculated from the TA-XT2i texture analyzer and computer interface: hardness (maximum force that is exerted on the sample), defined as the force necessary to attain a given deformation; adhesiveness (total negative area), the work necessary for overcoming the force of attraction between the area of foodstuff and other solids coming into contact with them; and cohesiveness (adhesive force), defined as forces of internal bonds, which keep the product as a whole. All determinations were carried out in triplicate.

\section{Apparent Viscosity Measurements}

Apparent viscosity measurements on yogurt samples were carried out at room temperature $\left(22 \pm 2^{\circ} \mathrm{C}\right)$ using 
a Brookfield DV-E Viscometer (Brookfield Engineering Laboratories Inc., Middleboro, MA), equipped with a No. 64 spindle running at different speeds ranging from 12 to $20 \mathrm{rpm}$. For relative comparison between treatments, viscosity reading was taken at the point of the 30th second and torque was maintained at all times between 10 and $100 \%$. All viscosity measurements were performed in triplicate.

\section{The Sensory Evaluation Analysis}

The sensory evaluation analysis was carried out according to the method of Soukoulis and Tzia (2008). Seven trained panelists were selected to evaluate the difference in perception of flavor, coarseness, syneresis, and overall quality of yogurt using a 5-point descriptive scale. Samples were tempered at $-4^{\circ} \mathrm{C}$ before sensory assessment. Samples were placed onto white plastic plates and coded using a 3-digit random number and served successively to the panelists in individually partitioned booths.

\section{Data Analysis}

All fermentation was carried out in triplicate. Statistical analyses were conducted using SPSS 14.0 for Windows (SPSS Inc., Chicago, IL). One-way ANOVA with Duncan's post-test were used. A probability level of $P<0.05$ was used throughout this study. Data were expressed as mean values \pm standard deviations.

\section{RESULTS AND DISCUSSION}

\section{Purification of TGase}

Streptomyces has been reported to produce TGase with low specific activities ranging from 0.13 to 0.28 $\mathrm{U} / \mathrm{mg}$ of protein in the culture (Ando et al., 1989; Gerber et al., 1994; Cui et al., 2007). Other reports discovered that the recombinant strains could produce active TGase with higher specific activities (Lin et al., 2007; Yu et al., 2008). Because of the risk of recom- binant strains, however, optimizing the production of TGase from wild strain becomes necessary. In the present study, the specific activity of TGase reached 2.9 $\mathrm{U} / \mathrm{mg}$ of protein in the excessive $\mathrm{MgCl}_{2}$ culture by $S$. mobaraensis DSM 40587, which was significantly higher than those of the above-mentioned reports. It appeared that the TGase produced in the present study was also easier to purify because of lower contents of other miscellaneous proteins in the culture.

Many studies of TGase from Streptomyces have been reported. No set rules exist for the purification of TGase. After separating the culture from the fermentation broth by filtration or centrifugation, the culture supernatant is concentrated by means of ultrafiltration or salting out by solid ammonium sulfate or ethanol. In the present study, because significant $\mathrm{MgCl}_{2}$ was present in the culture, the addition of solid ammonium sulfate resulted in increased salt precipitation. Ethanol can flocculate TGase and reduce its activity. Therefore, ultrafiltration was an effective and efficient concentration step. After ultrafiltration, the broth was reduced to one-fifth of the original volume. Under these conditions, about $99 \%$ of the enzyme activity was retained with a 1.1-fold increase in the specific activity (Table $1)$. As the culture contained many salts, ion-exchange chromatography could not be used to purify the enzyme following ultrafiltration. Gel chromatography (Sephadex G 75) was used first to exclude the salts and some brown pigment absorbing strongly at 280nm (Figure 1). During SP Sepharose High Performance chromatography, TGase activity was detected as a symmetrical peak (Figure 1). At the end of the process, TGase was purified 5.9 fold with a yield of $74 \%$ and a specific activity of $17.20 \mathrm{U} / \mathrm{mg}$ of protein (Table 1 ).

The molecular mass of purified enzyme was estimated to be around $38 \mathrm{kDa}$ with SDS-PAGE (Figure 2), indicating that this enzyme was a monomeric protein (Figure 2). This result was in agreement with the reports of Ando et al. (1989), Cui et al. (2007), and Zotzel et al. (2003), and lower than that from Streptomyces spp. isolated in Brazilian soil (45 kDa; Macedo and Sato, 2009) and much higher than that from Bacillus subtilis

Table 1. Summary of purification of transglutaminase (TGase) from Streptomyces mobaraensis

\begin{tabular}{|c|c|c|c|c|c|}
\hline Purification step & $\begin{array}{l}\text { TGase activity } \\
\text { (U) }\end{array}$ & $\begin{array}{l}\text { Protein } \\
(\mathrm{mg})\end{array}$ & $\begin{array}{l}\text { Specific activity } \\
(\mathrm{U} / \mathrm{mg})\end{array}$ & $\begin{array}{l}\text { Purification } \\
\text { fold }\end{array}$ & $\begin{array}{c}\text { Yield } \\
(\%)\end{array}$ \\
\hline Fermentation liquid & 759 & 259 & 2.93 & 1 & 100 \\
\hline SP Sepharose High Performance ${ }^{1}$ & 561 & 33 & 17.20 & 5.9 & 74 \\
\hline
\end{tabular}

${ }^{1}$ GE Healthcare, Uppsala, Sweden. 
a)

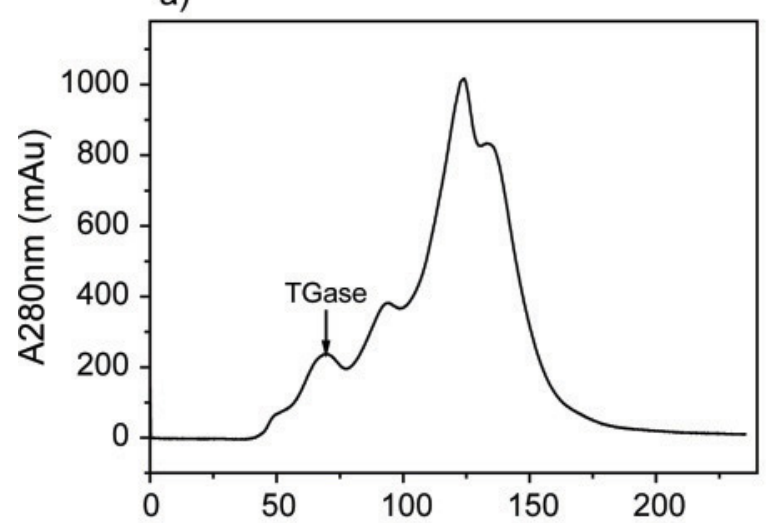

b)

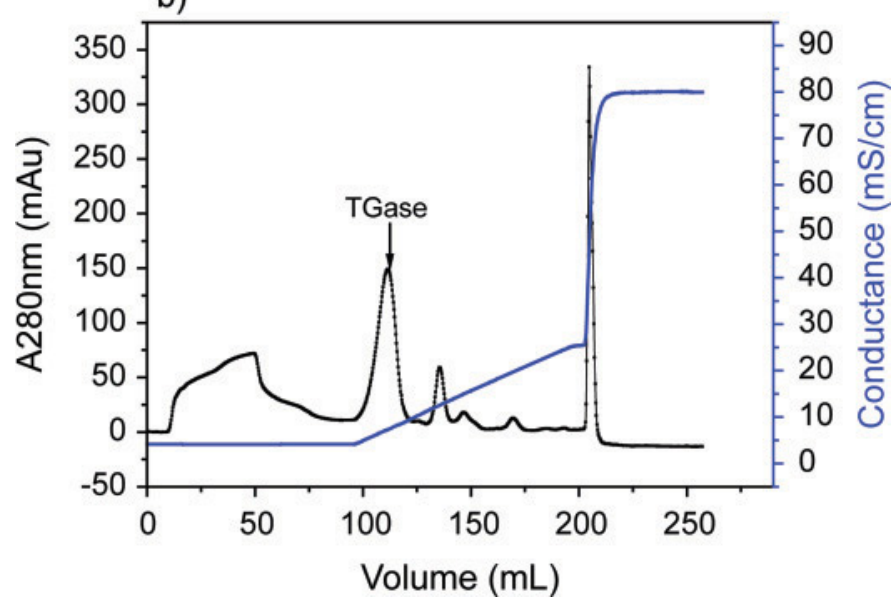

Figure 1. Chromatography of the crude transglutaminase (TGase) from Streptomyces mobaraensis DSM 40587 on Sephadex G-75 and SP Sepharose High Performance columns (GE Healthcare, Uppsala, Sweden). Transglutaminase was purified using the Sephadex G-75 (a) and then SP Sepharose High Performance column (b). The arrow indicates the active fraction containing TGase activity. Color version available in the online PDF.

(29 kDa; Suzuki et al., 2000). This difference may be due to differences in enzyme sources.

\section{Determination of Kinetic Parameters}

The effect of substrate concentration on the velocity of enzymatic reaction was determined at $\mathrm{pH} 6.0$ and $37^{\circ} \mathrm{C}$. The single straight line in the Lineweaver-Burk plot revealed that our assay system evaluated activity of a single enzyme. According to the Lineweaver-Burk plot (Figure 3), the $V_{\max }$ and $\mathrm{K}_{\mathrm{m}}$ of this enzyme were $44.44 \mathrm{U} / \mathrm{mg}$ of protein and $40.47 \mathrm{mmol} / \mathrm{L}$, respectively. The apparent $\mathrm{K}_{\mathrm{m}}$ was much higher than the report of Cui et al. (2007), but lower than the finding of Gerber et al. (1994). Such a discrepancy might be due to strain species differences or the conditions used in the assays, or both.

\section{Effect of pH on Enzyme Activity and Stability}

The effect of $\mathrm{pH}$ on TGase activity was determined using the reaction mixture as described previously at $\mathrm{pH} 3.0$ to 10.0 and at $37^{\circ} \mathrm{C}$. The enzyme showed optimum activity for the catalytic reaction of N-CBZ-GlnGly and hydroxylamine at $\mathrm{pH}$ 6.0, above 90\% activity between $\mathrm{pH} 4.0$ to 7.0 , and some residual activity at pH 3.0 and 10.0 (Figure 4a). The activity was found to decrease gradually at acidic $\mathrm{pH}$ and rapidly at alkaline $\mathrm{pH}$.

The purified TGase was stable between $\mathrm{pH} 5.0$ and 10.0 at $4^{\circ} \mathrm{C}$ for $12 \mathrm{~h}$ or between $\mathrm{pH} 5.0$ and 9.0 at $37^{\circ} \mathrm{C}$ for $30 \mathrm{~min}$. The activity decreased greatly outside of these ranges (Figure 4b).

The effect of $\mathrm{pH}$ on the activity and stability of the purified TGase from Streptomyces has been described (Ando et al., 1989; Cui et al., 2007). According to those

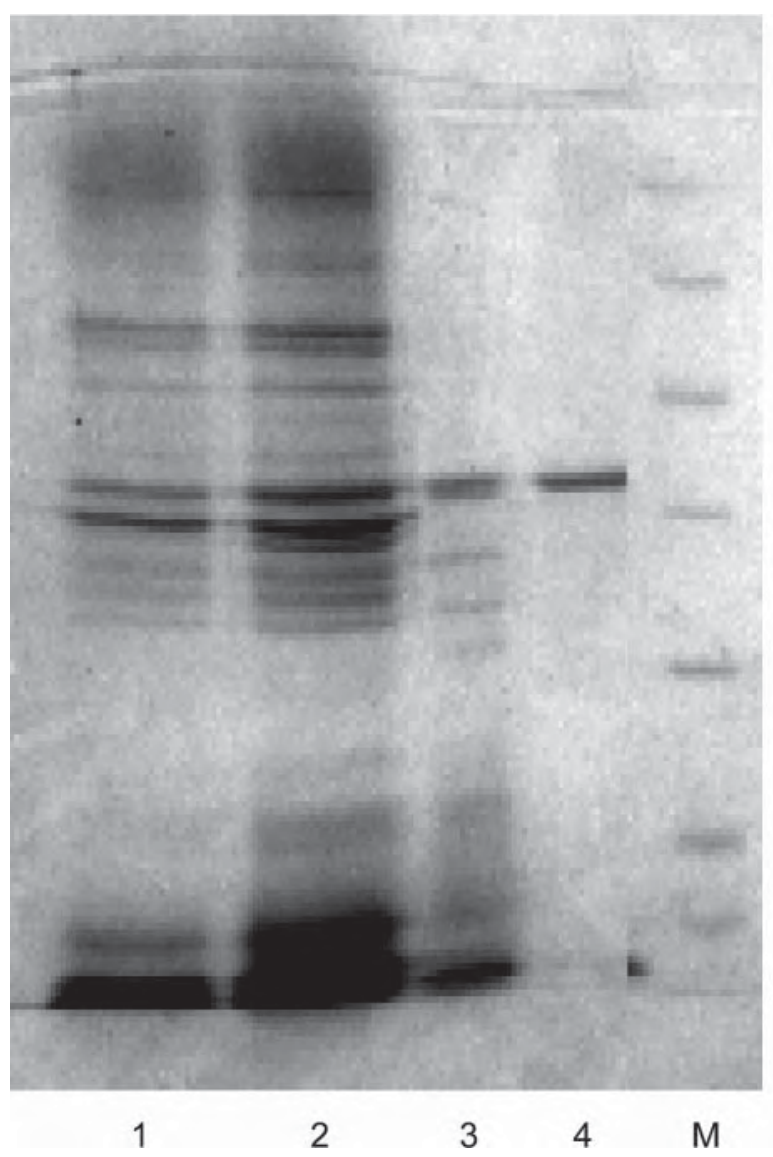

$\mathrm{kDa}$

116.0

66.2

45.0

35.0

25.0

18.4

14.4

Figure 2. Sodium dodecyl sulfate PAGE of transglutaminase (TGase) on acrylamide gel for crude enzyme, after ultrafiltration, Sephadex G-75 column, and SP Sepharose High Performance column chromatography. $\mathrm{M}=$ standard marker; lane $1=$ crude enzyme; lane $2=$ TGase after ultrafiltration; lane $3=$ TGase after Sephadex G-75; lane 4 = TGase after SP Sepharose High Performance chromatography. 


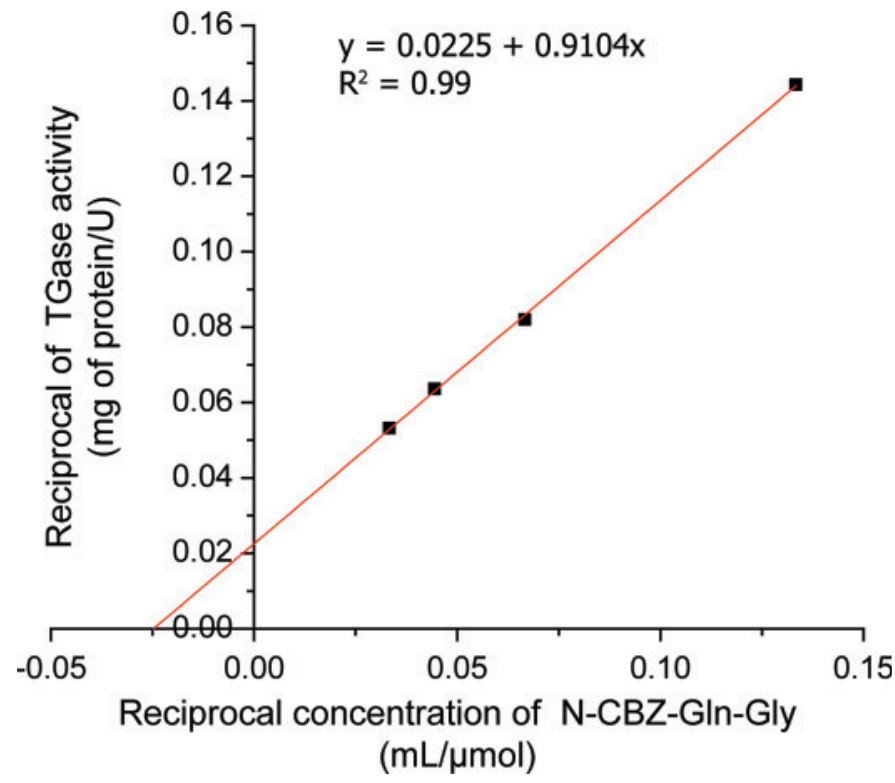

Figure 3. Lineweaver-Burk plot for Michaelis constant $\left(\mathrm{K}_{\mathrm{m}}\right)$ and maximum velocity $\left(\mathrm{V}_{\max }\right)$ values of the purified transglutaminase (TGase) in the presence of different concentrations of N-carboxybenzoyl-L-glutaminyl-glycine (N-CBZ-Gln-Gly). Color version available in the online PDF.

reports, the optimum $\mathrm{pH}$ is about 6 to 7 and the stable $\mathrm{pH}$ range is between 5.0 to 8.0. Compared with the previous results, the TGase purified in this study had a wider optimum and stable $\mathrm{pH}$ range.

\section{Effect of Temperature on Enzyme Activity and Stability}

The effect of temperature on TGase activity was investigated using N-CBZ-Gln-Gly and hydroxylamine as substrate at $\mathrm{pH} 6.0$ with incubating temperatures ranging from 20 to $70^{\circ} \mathrm{C}$. It was found that an optimum temperature for purified TGase was at $50^{\circ} \mathrm{C}$. Enzyme activity decreased markedly at temperatures below $42^{\circ} \mathrm{C}$ or above $55^{\circ} \mathrm{C}(P<0.05$; Figure 5a). A similar optimum temperature was reported earlier (Ando et al., 1989). However, Optimal temperatures of TGase between 37 and $45^{\circ} \mathrm{C}$ or 35 and $40^{\circ} \mathrm{C}$ have been reported for Streptomyces hygroscopicus (Cui et al., 2007) and Streptomyces spp. isolated from Brazilian soil (Macedo and Sato, 2009).

The heat stability of the enzyme tested after preincubation of the enzyme in the temperature range of 4 to $60^{\circ} \mathrm{C}$ for $30 \mathrm{~min}$ are shown in Figure 5b. Purified TGase maintained full activity after incubation for 30 min at $20^{\circ} \mathrm{C}$ and retained about $90 \%$ of the initial activity after incubation below $40^{\circ} \mathrm{C}$ during the same period. When the enzyme was incubated above $60^{\circ} \mathrm{C}$ for 30 min, however, its activity disappeared completely. In addition, the purified TGase retained more than $90 \%$ of its activity at $40^{\circ} \mathrm{C}$ for $30 \mathrm{~min}$, indicating it presented a higher thermal stability than that from S. hygroscopicus (Cui et al., 2007).

\section{Effect of Metal lons on Enzyme Activity}

The effects of various metals on TGase activity are shown in Table 2. Among the metal ions, TGase

a)

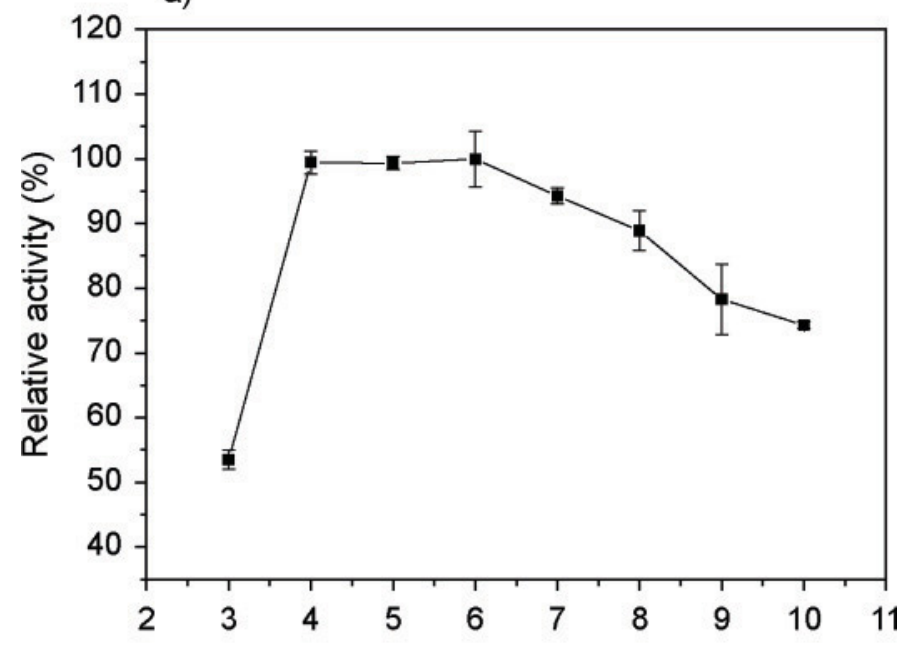

b)

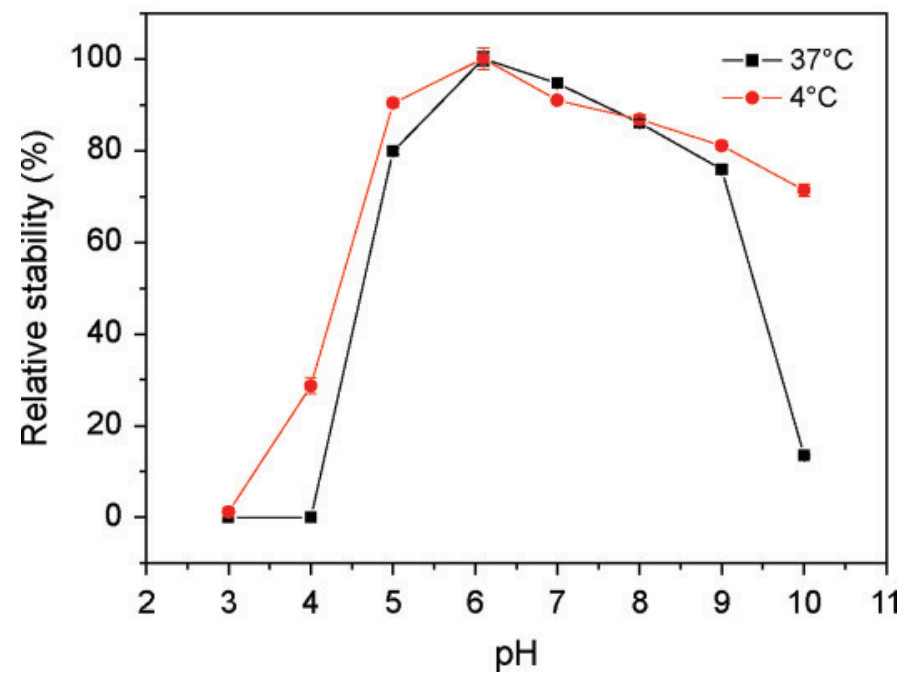

Figure 4. Effect of $\mathrm{pH}$ on the activity (a) and $\mathrm{pH}$ stability (b; $4^{\circ} \mathrm{C}$ for $12 \mathrm{~h} ; 37^{\circ} \mathrm{C}$ for $1 \mathrm{~h}$ ) of purified transglutaminase (TGase) from Streptomyces mobaraensis DSM 40587. The $\mathrm{pH}$ of the reaction mixture was adjusted with $50 \mathrm{~m} M$ acetate buffer (pH 3.7-6.0), $50 \mathrm{~m} M$ Tris$\mathrm{HCl}$ buffer ( $\mathrm{pH} 6.0-9.0$ ), and $50 \mathrm{~m} M$ borate buffer ( $\mathrm{pH} 10.0)$. All data were expressed as mean values $\pm \mathrm{SD}(\mathrm{n}=3)$. Color version available in the online PDF. 
Table 2. Effect of metal ions on transglutaminase (TGase) activity from Streptomyces mobaraensis DSM 40587

\begin{tabular}{lc}
\hline Metal ion $(5 \mathrm{~m} M)$ & Relative activity $^{1}(\%)$ \\
\hline None & $100.0 \pm 2.7^{\mathrm{a}}$ \\
$\mathrm{NaCl}$ & $101.0 \pm 2.9^{\mathrm{a}}$ \\
$\mathrm{BaCl}$ & $100.3 \pm 1.6^{\mathrm{a}}$ \\
$\mathrm{KCl}$ & $100.3 \pm 2.3^{\mathrm{a}}$ \\
$\mathrm{CaCl}_{2}$ & $99.7 \pm 0.8^{\mathrm{ab}}$ \\
$\mathrm{MnSO}_{4}$ & $94.6 \pm 0.6^{\mathrm{bc}}$ \\
$\mathrm{MgCl}_{2}$ & $93.7 \pm 5.1^{\mathrm{c}}$ \\
$\mathrm{FeSO}_{4}$ & $82.7 \pm 1.6^{\mathrm{d}}$ \\
$\mathrm{ZnCl}_{2}$ & $8.1 \pm 0.4^{\mathrm{e}}$ \\
$\mathrm{CuSO}_{4}$ & 0
\end{tabular}

${ }^{\mathrm{a} e}$ Values followed by different superscript letters in the same column are significantly different $(P<0.05)$.

${ }^{1}$ All data were expressed as mean values $\pm \mathrm{SD}(\mathrm{n}=3)$.

activity was not affected by $\mathrm{Na}^{+}, \mathrm{K}^{+}, \mathrm{Ba}^{2+}$, or $\mathrm{Ca}^{2+}$. However, it was slightly inhibited by $\mathrm{Mn}^{2+}, \mathrm{Mg}^{2+}, \mathrm{Fe}^{2+}$, and significantly by $\mathrm{Zn}^{2+}$ and $\mathrm{Cu}^{2+}(P<0.05)$. Under the same metal concentration, incubation time period, and temperature, the enzyme purified by Ando et al. (1989) was strongly inhibited only by $\mathrm{Zn}^{2+}$, moderately by $\mathrm{Pb}^{2+}$, and unaffected by $\mathrm{Cu}^{2+}$. However, the enzyme from $S$. hygroscopicus was strongly inhibited by $\mathrm{Zn}^{2+}$ and $\mathrm{Cu}^{2+}$ (Cui et al., 2007). These results show that the purified TGase is similar to S. hygroscopicus TGase.

\section{Crosslinking Effects of TGase on Yak and Cow Milk Yogurts}

To estimate the effects of TGase on yak yogurt, cow milk was chose for another control. The compositions of yak and cow milk are shown in Table 3. The contents of protein, fat, and total DM in yak milk were significantly higher compared with the cow milk. However, the higher contents of protein, fat, and total DM in yak milk caused the coarse texture.

The qualities of yogurts were evaluated by syneresis, viscosity, texture analysis, and sensory attributes. The results of physicochemical characteristics of yak and cow milk yogurt are presented in Table 4 .

The syneresis of yak yogurt was significantly distinct compared with the cow yogurt. The addition of TGase had no effects on the syneresis of yak yogurt. This may

Table 3. Comparison of the composition of yak and cow milk ${ }^{1}$

\begin{tabular}{lrr}
\hline Composition & Cow milk & \multicolumn{1}{c}{ Yak milk } \\
\hline Protein (\%) & $3.28 \pm 0.11$ & $6.32 \pm 0.23$ \\
Fat (\%) & $3.45 \pm 0.21$ & $5.68 \pm 0.37$ \\
Dry solid matter (\%) & $12.88 \pm 0.33$ & $17.97 \pm 0.69$ \\
Ash (\%) & $0.61 \pm 0.01$ & $0.88 \pm 0.02$ \\
SNF (\%) & $9.43 \pm 0.51$ & $11.98 \pm 0.49$ \\
\hline
\end{tabular}

${ }^{1}$ All data are expressed as mean values $\pm \mathrm{SD}(\mathrm{n}=3)$. a)

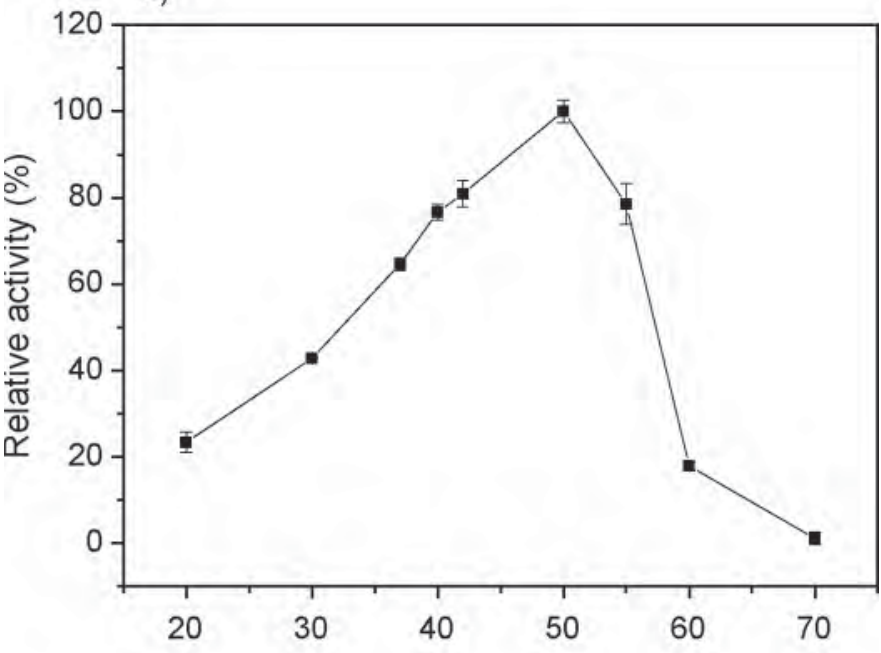

b)

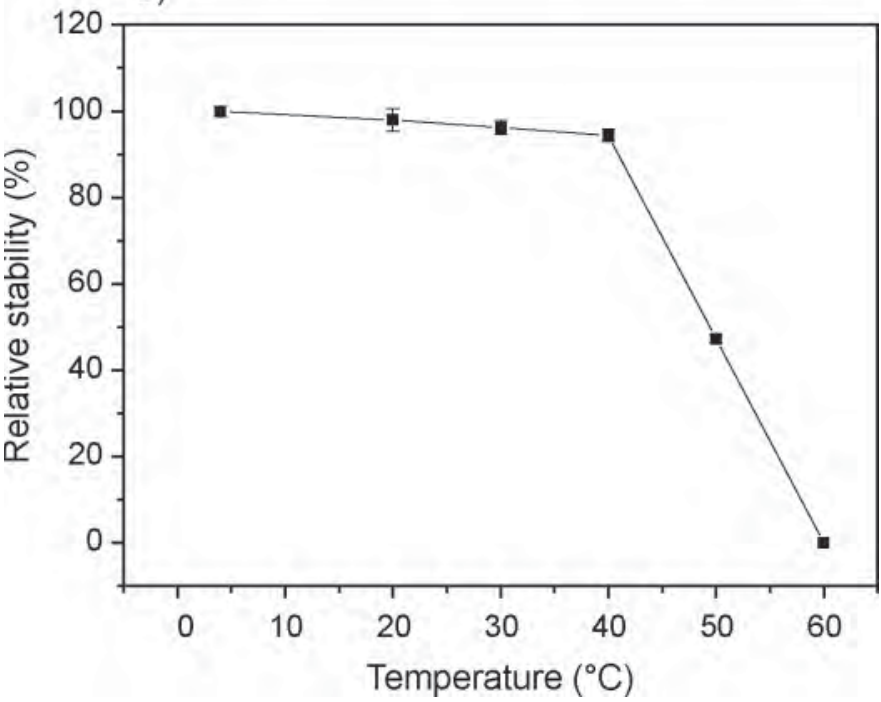

Figure 5. Effect of temperature on the activity (a) and stability (b) of purified transglutaminase (TGase) from Streptomyces mobaraensis DSM 40587. N-CBZ-Gln-Gly = N-carboxybenzoyl-L-glutaminylglycine. All data were expressed as mean values $\pm \mathrm{SD}(\mathrm{n}=3)$.

be because of that yak yogurt without TGase treatment presented a lower syneresis compared with cow milk yogurt. Researchers have found that yogurt with a higher TS content was less susceptible to syneresis. In addition, higher fat globule clusters in yak yogurt can fill up empty spaces between casein matrices to reduce syneresis (Trachoo, 2002).

The apparent viscosity varied from $4.3 \pm 0.3$ to 7.7 $\pm 0.7 \mathrm{~Pa} \cdot \mathrm{s}$ for cow yogurts and from $8.3 \pm 0.7$ to 27.4 $\pm 4.6 \mathrm{~Pa}$.s for yak yogurts. On average, for both kinds of yogurts, the increase in amount of TGase and the increase in apparent viscosities of yogurts when milk was treated with 0.5 to $2 \mathrm{U}$ of TGase/g of protein for cow yogurts and 0.25 to $1 \mathrm{U} / \mathrm{g}$ of protein for yak yo- 


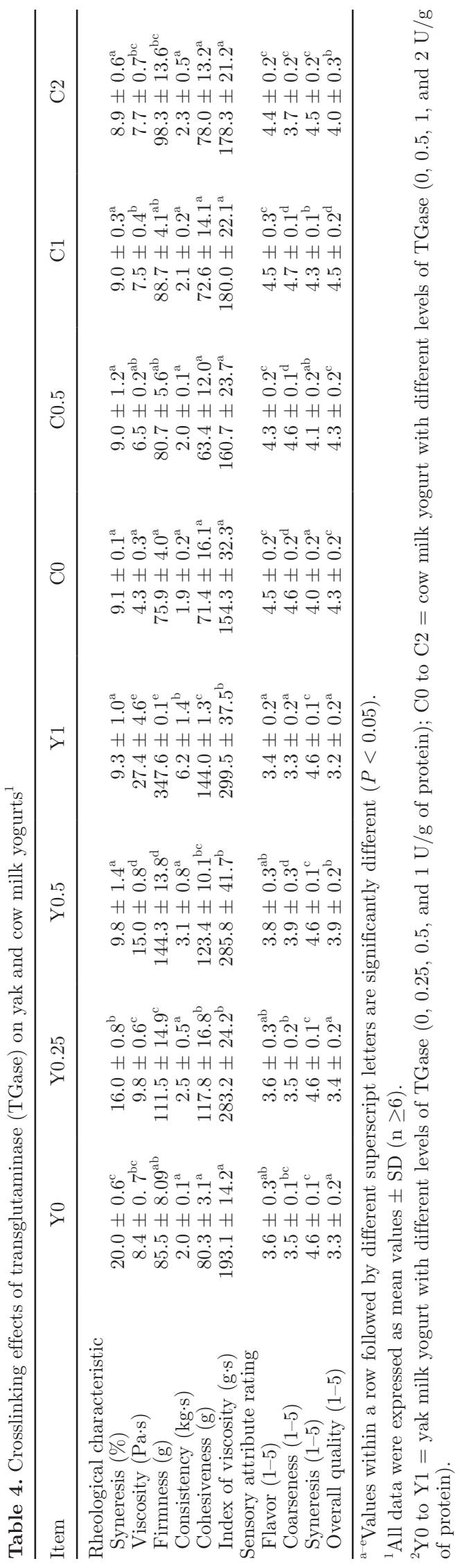

gurts, reached 181 and $327 \%$, respectively. These levels of increase for yak yogurts were much higher compared with cow yogurts.

Texture analysis is an important way to estimate the quality of yogurts. Firmness, consistency, cohesiveness, and index of viscosity for yak yogurts were significantly higher compared with the cow yogurts. In addition, these parameters of both kinds of yogurts were improved by TGase. Gauche et al. (2009) suggested that these higher values may be due to the additional $\varepsilon-(\gamma-$ glutamyl) lysine bonds created by TGase. The same results were obtained by Ozer et al. (2007) and Bönisch et al. (2007). They demonstrated that rheological properties could be related to a denser and finer gel network stabilized by covalently crosslinked protein polymers.

The production of crosslinking yogurts from yak and cow milk improved the body and texture of the product, which was reflected by the scores reported by sensory panel. Yak yogurt had significantly lower ratings for flavor, coarseness, and overall quality, except syneresis. Yak yogurt treated with $0.25 \mathrm{U}$ of TGase/mg of protein and cow yogurt with $0.5 \mathrm{U}$ of TGase/mg of protein had similar flavor, coarseness, syneresis, and overall quality as their own control yogurt. Increasing the TGase addition level to $0.5 \mathrm{U}$ of TGase/mg of protein for yak milk and $1 \mathrm{U}$ of TGase/mg of protein for cow milk yogurt improved flavor, coarseness, syneresis, and the overall acceptance ratings significantly compared with their control yogurt. Increasing the TGase addition level further decreased flavor, coarseness, and overall acceptance of both kinds of yogurt. Although the 4 yak yogurts had lower rating for flavor, coarseness, and overall quality, the yak yogurts treated with $0.5 \mathrm{U}$ of $\mathrm{TGase} / \mathrm{mg}$ of protein had significantly higher ratings for coarseness and overall quality than the yak control.

The SDS-PAGE electrophoretogram is very helpful for explaining the differences between the samples produced by different amounts of TGase (Figure 6). Similar to cow milk, the major protein bands were total casein, $\alpha_{\mathrm{s}}-\mathrm{CN}\left(\alpha_{\mathrm{s} 1}-\mathrm{CN}\right.$ and $\alpha_{\mathrm{s} 2}-\mathrm{CN}$ combined $), \beta-\mathrm{CN}$, $\kappa-\mathrm{CN}, \beta-\mathrm{LG}, \alpha-\mathrm{LA}$, and lactoferrin). Furthermore, the major proteins in yak milk are caseins; however, $\beta$-CN combines with $\alpha_{\mathrm{s}}$-CN firmly, presenting a single band. These results are generally in agreement with the reported values for Chinese yak milk (Sheng et al., 2008). The percentage amount of protein monomers in yogurt milk decreased upon enzymatic modification in TGase-treated yogurt compared with samples without TGase treatment ( $\mathrm{Y} 0$ and $\mathrm{C} 0$ ). Concomitantly, higher percentage amounts of protein oligomers were detected in enzymatically treated yogurt milk than in untreated yogurt milk. Furthermore, increasing the doses of enzyme supplemented into yogurts led to a further considerable decrease in $\mathrm{\kappa}$ - $\mathrm{CN}$ and increase in protein 


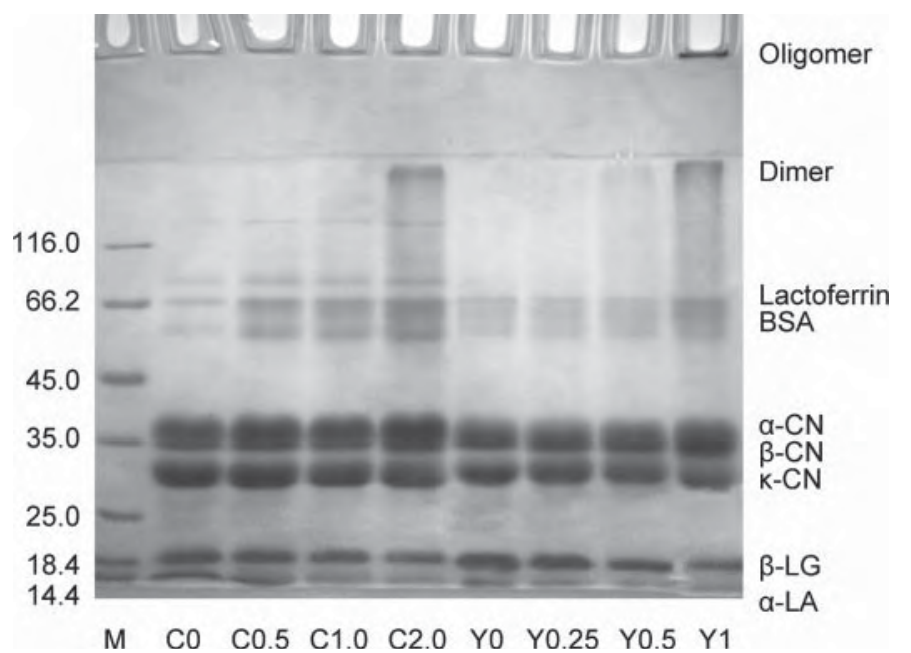

Figure 6. Electropherograms of yak and cow milk yogurts with and without crosslinking by transglutaminase (TGase). Lane $\mathrm{M}=$ molecular weight standard; lanes $\mathrm{Y} 0-\mathrm{Y} 1=$ yak milk yogurt with different levels of TGase $(0,0.25,0.5$, and $1 \mathrm{U} / \mathrm{g}$ of protein); lanes $\mathrm{C} 0-\mathrm{C} 2$ $=$ cow milk yogurt with different levels of TGase $(0,0.5,1$, and $2 \mathrm{U} / \mathrm{g}$ of protein).

aggregates with molecular masses between 66 and 116 $\mathrm{kDa}$ (Figure 6, lanes Y0.25, Y0.5, Y1, C0.5, C1.0, and $\mathrm{C} 2.0)$. No evidence of crosslinking of $\kappa$-casein and $\beta$-LG by the enzyme existed when the lower doses of TGase $(0.5 \mathrm{U} / \mathrm{mg}$ of protein for cow milk yogurt and $0.25 \mathrm{U} /$ mg of protein for yak milk yogurt) were applied to yogurt. However, both casein and $\beta$-LG were crosslinked with the increase in TGase. Furthermore, the majority of the casein and $\beta$-LG polymers were too large to enter the running gel, indicating molecular weights well above $200 \mathrm{kDa}$. The missing of the bands representing caseins and $\beta-\mathrm{LG}$ were good substrates for TGase, as reported in previous studies (Ozer et al., 2007).

\section{CONCLUSIONS}

Streptomyces TGase purified from high-salt medium was characterized and added to yak yogurts. These results elucidated that purified TGase has higher temperature and $\mathrm{pH}$ stability than the previously reported TGase from Streptomyces. Transglutaminase treatment of milk proteins modified their functional properties, such as solubility and hydration ability, and rheological and emulsifying properties and improved protein heat stability. It was found that TGase-catalyzed crosslinking was effective in improving properties of stirred yak yogurt. Treated yogurt produced a strong acid gel, higher consistency, cohesiveness, and index of viscosity and more creamy sensation than untreated product. Therefore, it is suggested that yak dairy products (e.g., yogurt, cheese with reduced fat, and protein) could be produced having textures similar to the full-fat and high-TS products. In other words, TGase can be used to pave the way for exploration of novel yak products overcoming the peculiar wet yak hair or sweat odor, or both.

\section{ACKNOWLEDGMENTS}

This work was financially supported by the National Natural Science Foundation of China (30972041/ C110602), Excellence Person Foundation of Harbin City (2010RFXXN039), Natural Science Foundation of Heilongjiang Province (ZJN0605-02), and Science \& Technology Program of Heilongjiang Province (GA07B401-1).

\section{REFERENCES}

Ando, H., M. Adachi, K. Umeda, A. Matsuura, M. Nonaka, R. Uchio, H. Tanaka, and M. Motoki. 1989. Purification and characteristics of a novel transglutaminase derived from microorganisms. Agric. Biol. Chem. 53:2613-2617.

AOAC. 2002. Methods of Analysis. Revision 1. 17th ed. Association of Official Analytical Chemists International, Arlington, VA.

Bönisch, M. P., M. Huss, K. Weitl, and U. Kulozik. 2007. Transglutaminase cross-linking of milk proteins and impact on yoghurt gel properties. Int. Dairy J. 17:1360-1371.

Bradford, M. M. 1976. A rapid and sensitive method for the quantitation of microgram quantities of protein utilizing the principle of protein-dye binding. Anal. Biochem. 72:248-254.

Cui, L., G. Du, D. Zhang, H. Liu, and J. Chen. 2007. Purification and characterization of transglutaminase from a newly isolated Streptomyces hygroscopicus. Food Chem. 105:612-618.

DeJong, G. A. H., and S. J. Koppelman. 2002. Transglutaminase catalyzed reactions: Impact on food applications. J. Food Sci. 67:2798-2806.

Farnsworth, J. P., J. Li, G. M. Hendricks, and M. R. Guo. 2006. Effects of transglutaminase treatment on functional properties and probiotic culture survivability of goat milk yogurt. Small Rumin. Res. 65:113-121.

Folk, J. E., and P. W. Cole. 1966. Mechanism of action of guinea pig liver transglutaminase. J. Biol. Chem. 241:5518-5525.

Gauche, C., T. Tomazi, P. L. M. Barreto, P. J. Ogliari, and M. T. Bordignon-Luiz. 2009. Physical properties of yogurt manufactured with milk whey and transglutaminase. Lebenson. Wiss. Technol. 42:239-243.

Gerber, U., U. Jucknischke, S. Putzien, and H. L. Fuchsbauer. 1994. A rapid and simple method for the purification of transglutaminase from Streptoverticillium mobaraense. Biochem. J. 299:825-829.

Kandeepan, G., and S. Sangma. 2011. Comparison of quality characteristics of full fat and low fat paneer developed from yak milk. Int. J. Dairy Technol. 64:117-120.

Keogh, M. K., and B. T. O'Kennedy. 1998. Rheology of stirred yogurt as affected by added milk fat, protein and hydrocolloids. J. Food Sci. 63:108-112.

Laemmli, U. K. 1970. Cleavage of structural proteins during the assembly of the head of Bacteriophage T4. Nature 227:680-685.

Lee, H. C., and K. B. Chin. 2010. Application of microbial transglutaminase and functional ingredients for the healthier low-fat/salt meat products: A review. Korean J. Food Sci. Anim. Resour. 30:886-895.

Lin, S.-J., Y.-F. Hsieh, P.-M. Wang, and W.-S. Chu. 2007. Efficient purification of transglutaminase from recombinant Streptomyces platensis at various scales. Biotechnol. Lett. 29:111-115.

Liu, H. N., F. Z. Ren, L. Jiang, Z. L. Ma, H. J. Qiao, S. S. Zeng, B. Z. Gan, and H. Y. Guo. 2011. Short communication: Fatty acid 
profile of yak milk from the Qinghai-Tibetan Plateau in different seasons and for different parities. J. Dairy Sci. 94:1724-1731.

Lorenzen, P. C., H. Neve, A. Mautner, and E. Schlimme. 2002. Effect of enzymatic cross-linking of milk proteins on functional properties of set-style yogurt. Int. J. Dairy Technol. 55:152-157.

Macedo, J., and H. Sato. 2009. Purification and characterization of a new transglutaminase from Streptomyces spp. isolated in Brazilian soil. New Biotechnol. 25:S125.

Motoki, M., and K. Seguro. 1998. Transglutaminase and its use for food processing. Trends Food Sci. Technol. 9:204-210.

Ozer, B., H. A. Kirmaci, S. Oztekin, A. Hayaloglu, and M. Atamer 2007. Incorporation of microbial transglutaminase into non-fat yogurt production. Int. Dairy J. 17:199-207.

Şanlı, T., E. Sezgin, O. Deveci, E. Şenel, and M. Benli. 2011. Effect of using transglutaminase on physical, chemical and sensory properties of set-type yoghurt. Food Hydrocoll. 25:1477-1481.

Sheng, Q. H., J. C. Li, M. S. Alam, X. P. Fang, and M. R. Guo. 2008. Gross composition and nutrient profiles of Chinese yak (Maiwa) milk. Int. J. Food Sci. Technol. 43:568-572.

Soares, L. H. B., P. M. Albuquerque, F. Assmann, and M. A. Z. Ayub. 2004. Physicochemical properties of three food proteins treated with transglutaminase. Ciência Rural 34:1219-1223.

Soukoulis, C., and C. Tzia. 2008. Impact of the acidification process, hydrocolloids and protein fortifiers on the physical and sensory properties of frozen yogurt. Int. J. Dairy Technol. 61:170-177.

Suzuki, S., Y. Izawa, K. Kobayashi, Y. Eto, S. Yamanaka, K. Kubota, and K. Yokozeki. 2000. Purification and characterization of novel transglutaminase from Bacillus subtilis spores. Biosci. Biotechnol. Biochem. 64:2344-2351.

Tang, C. H., L. Chen, and E. A. Foegeding. 2011. Mechanical and water-holding properties and microstructures of soy protein isolate emulsion gels induced by $\mathrm{CaCl}_{2}$, glucono- $\delta$-lactone (GDL), and transglutaminase: Influence of thermal treatments before and/or after emulsification. J. Agric. Food Chem. 59:4071-4077.

Trachoo, N. 2002. Yogurt: The fermented milk. Songklanakarin J. Sci. Technol. 24:727-737.

Yu, Y.-J., S.-C. Wu, H.-H. Chan, Y.-C. Chen, Z.-Y. Chen, and M.T. Yang. 2008. Overproduction of soluble recombinant transglutaminase from Streptomyces netropsis in Escherichia coli. Appl. Microbiol. Biotechnol. 81:523-532.

Yüksel, Z., and Y. K. Erdem. 2010. The influence of transglutaminase treatment on functional properties of set yogurt. Int. J. Dairy Technol. 63:86-97.

Zeng, S. S., S. S. Chen, B. Bah, and K. Tesfai. 2007. Effect of extended storage on microbiological quality, somatic cell count, and composition of raw goat milk on a farm. J. Food Prot. 70:1281-1285.

Zhang, H., Q. Wang, and E. Fan. 2009. Stability profile of fatty acids in yak (Bos grunniens) kidney fat during the initial stages of autoxidation. J. Am. Oil Chem. Soc. 86:1057-1063.

Zotzel, J., P. Keller, and H.-L. Fuchsbauer. 2003. Transglutaminase from Streptomyces mobaraensis is activated by an endogenous metalloprotease. Eur. J. Biochem. 270:3214-3222. 